\title{
Realising the Objectives of Infrastructure Master Plan: The Role of Internal Operatives
}

\author{
INNOCENT MASUNUNGURE \\ Postgraduate School of Engineering Management, \\ Faculty of Engineering and the Built Environment \\ University of Johannesburg \\ Bunting Road, Cottesloe, Auckland Park, Johannesburg, 2028 \\ SOUTH AFRICA \\ EDOGHOGHO OGBEIFUN \\ Postgraduate School of Engineering Management, \\ Faculty of Engineering and the Built Environment \\ University of Johannesburg \\ Bunting Road, Cottesloe, Auckland Park, Johannesburg, 2028 \\ SOUTH AFRICA \\ JAN-HARM C PRETORIUS \\ Postgraduate School of Engineering Management, \\ Faculty of Engineering and the Built Environment \\ University of Johannesburg \\ Bunting Road, Cottesloe, Auckland Park, Johannesburg, 2028 \\ SOUTH AFRICA
}

\begin{abstract}
The infrastructure master plan, in a higher education institution, serves as a blueprint for the coordinated and progressive development of the physical infrastructure and services to create a suitable academic environment required to promote teaching, learning and research. Implementation of master plan or organisation strategy is usually long-term, subject to rational and objective adjustment due to internal and external dynamics. Management and other internal role players were faced with dynamic economic and social circumstances that called for responsive and adaptive decision-making to implement the infrastructure master plan successfully. The single site case study method of qualitative research was adopted in the exploration of the development and implementation process of the infrastructure master plan of a higher education institution in Zimbabwe. The findings revealed that internal and external dynamics were managed through the collaborative relationship and participatory leadership of the University Council (Board), Building Committee and the Works Department of Estates of the institution. This provided stability and focused developments, while trying to cope with divergent pressure. The strategic infrastructure development of the master plan was achieved through the innovative use of multiple prong development strategies, which included new construction, rehabilitation of existing buildings, the purchase and renting of suitable properties.
\end{abstract}

Keywords: Higher education institution, Infrastructure master plan, Strategy, Implementation, Internal operatives

Received: March 12, 2021. Revised: September 24, 2021. Accepted: October 15, 2021. Published: November 4, 2021.

\section{Introduction}

Infrastructure for any organisation, including higher education (HE) institutions refers to the facilities and services that facilitate and support the execution of activities, which are crucial for the achievement of the goals and objectives of the organisation [1]. The infrastructure master plan of HE institutions serves as the blueprint for realizing the physical infrastructure and services requirement of the institution that creates a suitable academic environment for teaching, 
learning and research. The implementation process usually requires long-term operation that involves progressive, rational, and objective modification due to the dynamics of the academic institution. The modifications can be influenced by the growth in student enrolment, diversification, and specialisation in academic programmes, as well as other internal and external factors. However, some factors may impact negatively on the development and implementation of a suitable infrastructure master plan. These include, but are not limited to, long delays in plan preparation and approval processes, lack of coordination and effective communication among stakeholders, inadequate financial resources, gaps in the legal framework, and the lack of political will [2].

The development of an infrastructure master plan aimed at achieving the objectives of any $\mathrm{HE}$ institution requires functional implementation strategies. Pella et al. in reference [3] suggest that organisations should pay close attention to the development of functional implementation strategies so that the objectives of the master plans can be achieved. A review of literature shows that considerable research has paid more attention to strategy formulation or master plan development, than to strategy or master plan implementation. Li et al. [4], p. 6] defined strategy or master plan implementation as "a dynamic, iterative and complex process, which comprises of a series of decisions and activities by managers and employees - affected by a number of interrelated internal and external factors to turn strategic plans into reality in order to achieve strategic objectives". It involves taking actions and decisions to bridge the gap between the actual and the formulated strategy by responding to the changing internal and external circumstances [5]. The execution of an infrastructure master plan is a daunting task for any management team, the failure rate reported in literature is as high as between $70-90 \%$, due to defective implementation strategies $[5,6]$. Therefore, to ameliorate this high failure rate, leaders and top management of organisations should commit and devote sufficient time to strategy implementation during the project execution stage $[7,8]$. In this regard, it is imperative for top managers of $\mathrm{HE}$ institutions (like other organisations) to navigate the infrastructure master plan implementation by considering all internal and external factors that could have a potential negative influence on the intended outcome of the implementation process. Internal institutional dynamics such as organizational structure, top management support, culture, allocation of resources, consultation, the active involvement, and coordination of all strategic and tactical managers have an overarching influence on the effective execution of the strategic direction $[9,10,12,13]$. The role of internal role players is, therefore, key in managing the execution of the infrastructure master plan, coordinating the effective use of available resources and the organisation's need to respond to changing demands of the internal and external environment.

This paper is an excerpt from larger research into the development and implementation of an infrastructure master plan by an $\mathrm{HE}$ institution in Zimbabwe. The institution opened its doors to the first group of students in the year 2000, using the physical facilities of a former teachers' college. The institution crafted its first strategic plan in 2001 which covered a period of 15 years, wherein it outlined the strategic infrastructure development master plan (SIDMP) or the facilities master plan, which would support its core academic function, goals, and objectives [14]. During the implementation phase of the SIDMP, there were many internal and external challenges to the institutional environment. These included the country (Zimbabwe) facing its worst economic challenges characterised by hyper-inflation, low gross domestic product (GDP), political and economic sanctions, a massive brain drain and high unemployment $[15,16]$. The cost of putting up new brick and mortar structures was a daunting task with inflation rising each year since 2003. In January 2004 inflation was reported to be $623 \%$ and skyrocketed to unprecedented levels of 231 million percent in 2008. This situation forced Zimbabwe to abandon its local currency and adopt a multiple currency financial system that included the United States dollar, the South African rand, and the Botswana pula in January 2009 [17, 18].

The initial SIDMP goal was to establish 11 faculties and supporting administrative facilities and infrastructure on a single campus by the year 2015 [14]. However, this strategic goal changed in many dimensions resulting in the development of multiple campuses in different geographical locations, significant modification of the academic programmes and objective. Nevertheless, the institution was able to execute a significant proportion of the planned SIDMP by adopting several innovative approaches, which included new construction, rehabilitation, refurbishment and adaptation of existing facilities, rental and purchase of suitable properties. In this 
regard, the focus of this paper is to explore the roles played by the internal role players during the implementation of the SIDMP, keeping to the terms of the facilities master plan and how management manoeuvred through highly challenging environments to achieve the objectives of the SIDMP.

\section{Literature Review}

\subsection{Infrastructure Master Plan in a Higher Education Institution}

A campus infrastructure master plan or facility master plan is the physical representation of the education plan that is developed by considering capacity and the state of existing facilities, future demand, the gap between student enrolment increase and decrease, the strategies and projects to close the gap [19]. Campus master plans outline the physical infrastructure, their location, campus traffic layout (pedestrian walkways and vehicular routes), utility requirements (power supply, water, sewerage and ICT infrastructure), and necessary land improvements or acquisitions [8]. It attempts to relate or connect the institution's vision and mission statements to the physical learning environment. An effective master plan must aim to utilize the limited resources at the disposal of an institution's management for orderly and systematic growth, and development in pursuance of its strategic goals [12]. Rudden [13] underscores that, although a campus master plan does not predict the campus future, it provides a productive and valuable road map for the future development of the campus.

The development and implementation of an infrastructure master plan for an $\mathrm{HE}$ institution requires a huge funding investment [19]. However, the reality facing public HE institutions is that state funding and support are not continuously steady, a situation that demands prudent management of available resources as well as the exploration and mobilisation of alternative resources [2, 12].

The effective execution of an infrastructure master plan requires wide consultations with relevant stakeholders to enable the consolidation of shared development goals and resolve conflicting objectives in a rational and accountable way [20]. The consultation process also facilitates the effective communication of the aspirations, culture and set of values embedded in the master plan and helps to build understanding, trust, and buy-in by all the stakeholders $[12,20,21]$. The development of a facility master plan ensures full assessment of the prevailing situation in relation to conditions of existing facilities, analysis of future needs and the development of an infrastructure improvement plan [22]. It also acts as a benchmark for undertaking an assessment of priorities and deficiencies and as a basis of aligning strategy to overall organisational goals. HE institutions achieve different degrees of implementation of their infrastructure master plans due to several contending factors that are both internal and external to the respective institutions.

\subsection{Factors Influencing the Implementation of an Infrastructure Master Plan}

Several factors have a bearing on the implementation process of a typical infrastructure master plan, as shown in Figure 1.

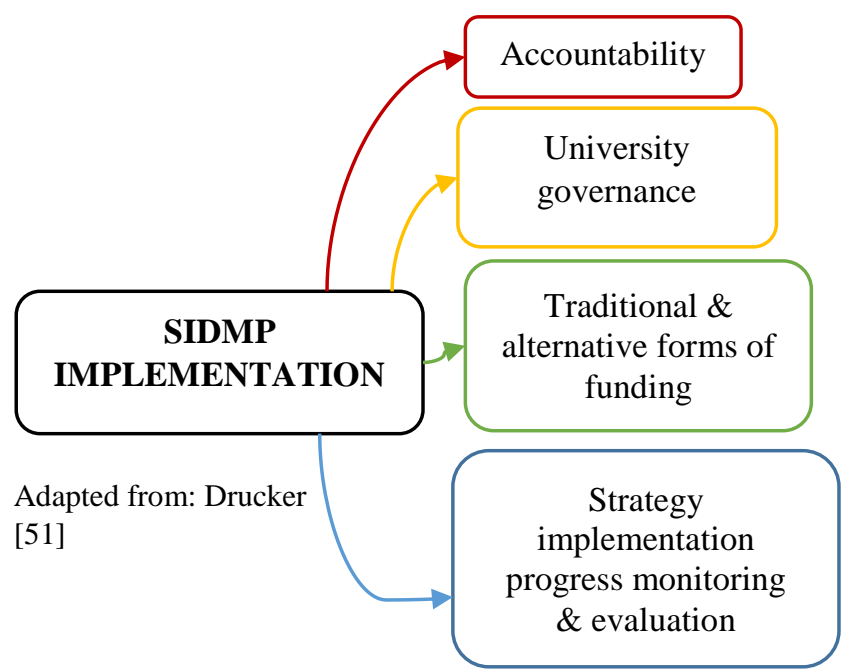

Fig. 1: Factors Influencing Implementation of SIDMP

\subsubsection{University Governance}

The processes of implementing infrastructure master plans by public institutions are significantly influenced by the governance structure of the respective institutions [24]. One of the strengths of a typical HE institution is the autonomy of its governance system. This provides for the separation of powers, management planning flexibility and an independent bargaining strategy with relevant stakeholders. In most instances, political players seek to influence the strategy whilst the management may be having their own goals overridden by the need for stakeholder participation. Bryson [25] concurs that public institutions exist within a political environment. The interference and process of involving stakeholders can be time consuming, costly 
and can lead to governance problems [26]. The changes in political administration can also bring new members into the management fold, which can affect the governance and the implementation process of infrastructure projects that span long periods of time.

An effective governance system requires the deployment of suitable resources for the implementation of the infrastructure master plan. These resources include financial, technological and human capacity [20, 21]. Strategy implementation can be limited by human resources and problems linked to recruitment and inadequate training, among others [9]. Retaining critical skills is now more important in the current knowledge-based environment where human and technological resources occupy the central position for organisational strategy, which is different from the land and capital, in the traditional model [28]. The management of an HE institution should ensure progressive and periodic training of personnel involved in the implementation of an infrastructure master plan to ensure professional excellence, innovative modifications compliant with current trends in technology, pedagogy and suitable academic environments $[25,28]$.

\subsubsection{The Question of Accountability}

The implementation of an infrastructure master plan by any $\mathrm{HE}$ institution, requires a large amount of money, sourced from different avenues, both public and private. Proper accountability for the funds and the effective use of the funds, influence further funding and the degree of implementation of the master plan. Corporate scandals make the public and stakeholders shun the implementation process and at times the sponsors may withdraw their funding [24]. The public eye does not leave room for error. Once the public develops a negative opinion pertaining to accountability, the institutions may fail to recover. It is therefore imperative for the HE institutions to ensure proper accountability.

The successful implementation of a strategy requires resources and demonstrate value for money to the public [24]. In a bid to increase accountability in $\mathrm{HE}$, some state-funding systems now include performance-based funding schemes as a way of deriving value for money on the utilisation of other HE state-funding instruments such as enrolment-based funding instruments and any other funding instrument $[30,31]$. As public funding for universities dwindles, HE management is encouraged to develop capital improvement plans that demonstrate how to achieve maximum financial benefit from investments in major construction and renovation projects [32] to demonstrate accountability to all stakeholders who sponsor the institutions' capital budgets.

\subsubsection{Traditional and Alternative Forms of Funding}

Public HE institutions serve the dual purpose of improving the lives of citizens and the development of human capacity [31]. To perform this role, public institutions require adequate financial resources. Traditional sources of funding for HE have been state funding (grants, student loans), own incomes of educational institutions (research, assets, rents, fees, commercial ventures, etc.), financial support from individuals and enterprises interested in education in the form of donations and sponsorships (educational supplies/equipment, sports, transport, etc.) and loans or grants offered by financial institutions. State funding has been the main source of funding for both operational and capital expenditure, and the levels of funding vary from country to country depending on the country's budget system structure, economic performance and competing fiscal needs [31, 33]. Capital requirements for the development of infrastructure and buildings are usually remarkably high and as a result most countries increasingly fail to fund universities adequately $[34,30,31]$. This can greatly affect the implementation of infrastructure master plans and therefore, challenge the university management to explore other alternative forms of funding such as long-term bank loans/debt and publicprivate partnership arrangements, which are a common strategy for funding facilities that bring in revenue such as halls of residences, bookstores, training and resource centres etc. [35, 8]. Challenges associated with funding of $\mathrm{HE}$ differs from state to state and include "inadequate budgetary support, inadequate funds for capital development, lack of programme differentiated unit cost in provision of funds from government, inadequate internal income generation by the universities, and system inefficiencies" [31, p. 38], among others.

\subsubsection{Implementation Progress Monitoring and Evaluation}

Monitoring and evaluation are two words often mentioned hand in glove, but their application involves distinctly different functions. Otieno [36] separates the two terms and defines them as follows: 
"Monitoring is viewed as a process that provides information and ensures the use of such information by management to assess project effects - both intentional and unintentional - and their impact. Monitoring is the continuous assessment of a programme or project in relation to the agreed implementation schedule" [36, p. 41].

"Evaluation can be defined as a process which determines as systematically and as objectively as possible the relevance, effectiveness, efficiency, sustainability and impact of activities in the light of a project/programme performance, focusing on the analysis of the progress made towards the achievement of the stated objectives" [36, p. 43].

It is acknowledged that complexity and change define the current environment under which the public entities operate. Monitoring and evaluation or control and feedback as Okumus [9] puts it, involves the formal and informal mechanisms that allow the execution of strategy to be monitored and evaluated against predetermined objectives and set targets. As an important part of its evaluation, monitoring and coordinating role, the strategy execution team should track the progress of the implementation effort and report the results formally to senior management [9]. No matter how brilliant a facilities master plan is, executing it requires a planned approach and constant monitoring [37]. Ivancic et al. [38] contend that identifying and monitoring the environmental context characteristics helps managers determine the level of context uncertainty, and therefore how to respond to it in pursuance of the adopted strategy. A good understanding of the external environmental context enables managers to align an organization's strategy and adapt it to the external circumstances to enhance performance [39, 40]. Mnjama and Koech [41], in their study found that where an organisation had leadership that was committed to the implementation of the strategic plan and were actively involved in the monitoring and evaluation of the execution process, the success rate was higher. Therefore, it is imperative that senior management should identify key success factors for performance reporting and measurement. The use of up-to-date technology can result in the successful implementation of an infrastructure master plan. With novel technology, the entity can easily implement, evaluate and monitor its strategic process [24]. Technology is important for creating new knowledge and processes. Its availability and use in public sector entities can facilitate an infrastructure master plan implementation process [29].

\section{Research Method}

The single site case study strategy of qualitative research was adopted in the exploration of the development and implementation process of an infrastructure master plan of an $\mathrm{HE}$ institution in Zimbabwe. The qualitative research took the interpretivist paradigm that sought to understand how the research participants viewed, experienced and understood the phenomenon under investigation $[42$, $43,44]$.

The study sought to answer the following three research questions:

\section{i. Which of the SIDMP planned developments were implemented? \\ ii. What factors influenced the implementation of the SIDMP? \\ iii. How did these factors affect the evolvement/ implementation of the SIDMP?}

\subsection{Population, Sample, and Sampling Method}

The study population was drawn from the strategic and operational levels of leadership of the institution, which consists of senior administrative and academic management staff (strategic category) and middle administrative and technical management staff (operational category). These categories of participants were selected because they were involved in the implementation of the organisation's facilities master plan, and, therefore, knowledgeable about this research.

From the population, a purposive sample was drawn from the strategic and operational categories based on the position, role played, knowledge, and expertise of the participants [27]. Purposive or targeted sampling is based on the premise that the chosen sample has adequate and extensive knowledge about the subject of the research [38]. To preserve the anonymity of the participants, each respondent was simply identified by their management level. Table 1 provides the demography of the participants.

Table 1. Participant Demographics

\begin{tabular}{|l|c|c|c|}
\hline Pseudonyms & Age & $\begin{array}{c}\text { Management } \\
\text { level }\end{array}$ & $\begin{array}{c}\text { Period of } \\
\text { active } \\
\text { involvement in } \\
\text { the SIDMP }\end{array}$ \\
\hline Respondent 1 & 75 & Strategic & All 15 years \\
\hline Respondent 2 & 56 & Strategic & All 15 years \\
\hline Respondent 3 & 50 & Strategic & Partly, 12 years \\
\hline
\end{tabular}




\begin{tabular}{|c|c|c|c|}
\hline & & & from start \\
\hline Respondent 4 & 40 & Operational & $\begin{array}{c}\text { Partly, 8 years } \\
\text { from start }\end{array}$ \\
\hline Respondent 5 & 63 & Operational & All 15 years \\
\hline
\end{tabular}

\subsection{Data Collection and Analysis}

The primary instrument of the data collection was a semi-structured questionnaire, which was complemented by document analysis [44, 43]. The semi-structured questions (open-ended) were distributed by email to the respective participants [45]. Repeated follow-ups were made to the participants through email, telephone calls and short messaging service (SMS) communications, until adequate responses were received. The data collected through the document study, included three editions of strategic plans, policy documents, minutes of meetings, documents on strategy implementation processes, and periodic reports [43, 45]. The document analysis was used to substantiate and supplement evidence from the self-administered questionnaire [44].

The original university SIDMP contained 23 different infrastructure elements (buildings, sports facilities, and services - roads, water network, sewerage network; etc.) to be constructed. They were distributed across the proposed three-phase development plan period, as shown in Table 2.

Table 2. Projects Planned under the SIDMP

\begin{tabular}{|l|l|}
\hline & Project \\
\hline S/No & Phase 1: 2001-2005 \\
\hline $\mathbf{1}$ & $\begin{array}{l}\text { Adaptation \& Refurbishment of Existing } \\
\text { Former GTC Infrastructure }\end{array}$ \\
\hline $\mathbf{2}$ & Administration Block \\
\hline $\mathbf{3}$ & Faculty of Commerce \\
\hline $\mathbf{4}$ & Faculty of Law \\
\hline $\mathbf{5}$ & Faculty of Architecture Art \& Design \\
\hline $\mathbf{6}$ & Vice Chancellor's Residence \\
\hline & Phase 2: 2006-2010 \\
\hline $\mathbf{7}$ & Faculty of Science \& Technology \\
\hline $\mathbf{8}$ & University Chapel \\
\hline $\mathbf{9}$ & Sports Facilities \\
\hline $\mathbf{1 0}$ & Library Services \\
\hline $\mathbf{1 1}$ & Services \\
\hline $\mathbf{1 2}$ & Halls of Residence \\
\hline & Phase 3: 2011-2015 \\
\hline $\mathbf{1 3}$ & Faculty of Health Sciences \\
\hline $\mathbf{1 4}$ & $\begin{array}{l}\text { Faculty of Natural Resources Management } \\
\text { \& Agriculture }\end{array}$ \\
\hline
\end{tabular}

\begin{tabular}{|l|l|}
\hline $\mathbf{1 5}$ & Faculty of Engineering \\
\hline $\mathbf{1 6}$ & Faculty of Arts \\
\hline $\mathbf{1 7}$ & Faculty of Social Sciences \\
\hline $\mathbf{1 8}$ & Faculty of Education (Refurbishments) \\
\hline $\mathbf{1 9}$ & Great Hall \\
\hline $\mathbf{2 0}$ & Student Health Centre \\
\hline $\mathbf{2 1}$ & Student Union \\
\hline $\mathbf{2 2}$ & Non-Faculty Units \\
\hline $\mathbf{2 3}$ & Department of Estates \& Works \\
\hline
\end{tabular}

The principle of content analysis was used for the analysis of the qualitative data collected, which facilitated the "examining, categorising, tabulating, testing and recombining evidence to draw conclusions" [44, p. 126]. The synthesis of the analysed results assisted in the development of suitable themes from the collected data. The details of the process of analysis and results are discussed in detail in the section for findings and discussion.

\section{Findings}

This section presents the findings of the research and the discussion thereof.

\subsection{SIDMP Classification and Mode of Execution}

The synthesis of the data collected through the selfadministered questionnaire and document analysis shows how the planned 23 physical facilities listed in Table 2 were established over the 15 -year period of the SIDMP. The implementation process is classified into four categories, namely: "Implemented within planned period (IWPP)", "Implemented earlier than the planned period (IEPP)", "Implemented after planned period (IAPP)" and "Not implemented at all (NI)". Furthermore, four modes of execution were adopted in achieving the implementation of the SIDMP, namely: new construction, refurbishing and adaptation, rental and purchase of suitable properties. Table 3 provides the summary of the SIDMP components, the classification, mode of execution and the quantity of infrastructure executed in each cluster.

Table 3. Summary of the SIDMP Classification and Mode of Execution

\begin{tabular}{|c|c|c|c|c|}
\hline $\begin{array}{l}\mathrm{S} / \\
\mathrm{N}\end{array}$ & Classification & Mode of execution & Qty & $\begin{array}{l}\text { Total } \\
(\%)\end{array}$ \\
\hline \multirow[t]{2}{*}{1} & \multirow{2}{*}{$\begin{array}{l}\text { Implemented } \\
\text { within the } \\
\text { Planned }\end{array}$} & New construction & 3 & \\
\hline & & $\begin{array}{l}\text { Refurbishment \& } \\
\text { adaptation }\end{array}$ & 3 & $\begin{array}{c}13 \\
(56.5\end{array}$ \\
\hline
\end{tabular}




\begin{tabular}{|c|c|c|c|c|}
\hline & $\begin{array}{l}\text { Period } \\
\text { (IWPP), }\end{array}$ & $\begin{array}{l}\text { Rental/Purchase of } \\
\text { suitable property }\end{array}$ & 7 & $\%)$ \\
\hline \multirow[t]{3}{*}{2} & \multirow{3}{*}{$\begin{array}{l}\text { Implemented } \\
\text { earlier than the } \\
\text { Planned } \\
\text { Period (IEPP), }\end{array}$} & New construction & 1 & \multirow{3}{*}{$\begin{array}{l}2 \\
(8.7 \%)\end{array}$} \\
\hline & & $\begin{array}{l}\text { Refurbishment \& } \\
\text { adaptation/alterati }\end{array}$ & 1 & \\
\hline & & $\begin{array}{l}\text { Rental/Purchase of } \\
\text { suitable property }\end{array}$ & 0 & \\
\hline \multirow[t]{3}{*}{3} & \multirow{3}{*}{$\begin{array}{l}\text { Implemented } \\
\text { after the } \\
\text { Planned } \\
\text { Period (IAPP) }\end{array}$} & New construction & 4 & \multirow{3}{*}{$\begin{array}{l}4 \\
(17.4 \\
\%) \\
\end{array}$} \\
\hline & & $\begin{array}{l}\text { Refurbishment \& } \\
\text { adaptation }\end{array}$ & 0 & \\
\hline & & $\begin{array}{l}\text { Rental/Purchase of } \\
\text { suitable property }\end{array}$ & 0 & \\
\hline \multirow[t]{2}{*}{4} & Not & New construction & & 4 \\
\hline & $\begin{array}{l}\text { Implemented } \\
\text { at all (NI) }\end{array}$ & & 4 & $\begin{array}{l}(17.4 \\
\%)\end{array}$ \\
\hline
\end{tabular}

In a nutshell, $19(82.6 \%)$ of the planned projects were executed, with only 4 (17.4\%) of the 23 listed projects not executed.

\subsection{Factors that Affected the Implementation of the SIDMP}

The analysis of the participants' responses (horizontal and vertical analysis) provides the required insights to the research topic. The synthesis of the data was summarised, a process that assisted in developing suitable themes, as presented in Table 4. suitable themes.

Table 4. Analysis of Findings of Factors that Affected the Implementation of the SIDMP

\begin{tabular}{|c|c|c|c|}
\hline Survey question S/No & Synthesis & Summary & Suitable theme \\
\hline $\begin{array}{l}\text { 2. In your opinion, what were } \\
\text { the factors responsible for the } \\
\text { timely implementation of the } \\
\text { proposals in the master plan? }\end{array}$ & $\begin{array}{ll}\checkmark & \text { Adequate funding } \\
\checkmark & \text { Self-reliant policies } \\
\checkmark & \text { University autonomy } \\
\checkmark & \text { Learning from others }\end{array}$ & $\begin{array}{l}\checkmark \text { Adequate funding } \\
\text { Operational policies }\end{array}$ & \multirow{2}{*}{$\begin{array}{l}\text { Facilities master plan } \\
\text { implementation is } \\
\text { influenced by } \\
\text { resources and } \\
\text { operational policies }\end{array}$} \\
\hline $\begin{array}{l}\text { 3. What would you say was } \\
\text { responsible for the delays in the } \\
\text { execution or non-execution of } \\
\text { some of the infrastructure, as } \\
\text { planned? }\end{array}$ & $\begin{array}{ll}\checkmark & \text { Funding constraints } \\
\checkmark & \text { Moving from single to } \\
& \text { multiple campuses } \\
\checkmark & \text { Lack of technical skills } \\
\checkmark & \text { Hyperinflation in the } \\
& \text { country }\end{array}$ & $\begin{array}{ll}\checkmark & \text { Funding constraints } \\
\checkmark & \text { Inflation } \\
\checkmark & \text { Skills } \\
\checkmark & \text { Operational policies }\end{array}$ & \\
\hline $\begin{array}{l}\text { 4. Has the university remained } \\
\text { committed to the implementation } \\
\text { of the original infrastructure } \\
\text { master plan? Why do you say } \\
\text { so? }\end{array}$ & $\begin{array}{l}\checkmark \text { Commitment remained till } \\
2007 \text { \& changed thereafter. } \\
\checkmark \text { Strategy changed from } \\
\text { mono-campus to multi- } \\
\text { campus }\end{array}$ & $\begin{array}{l}\checkmark \text { Commitment shown by } \\
\text { use of own resources \& } \\
\text { engagement in public- } \\
\text { private partnerships }\end{array}$ & \multirow{2}{*}{$\begin{array}{l}\checkmark \text { Master plan is } \\
\text { dynamic } \\
\text { reflecting } \\
\text { prevailing } \\
\text { operational } \\
\text { strategies and } \\
\text { influenced by } \\
\text { internal and } \\
\text { external factors }\end{array}$} \\
\hline $\begin{array}{l}\text { 5. Has there been any revision } \\
\text { of the original infrastructure } \\
\text { master plan? If so, when and } \\
\text { what was revised? }\end{array}$ & $\begin{array}{ll}\checkmark & \text { Strategic plan revised in } \\
& 2005 \text { \& } 2014 \\
\checkmark & \text { Mission and strategy } \\
\text { changed } \\
\checkmark & \text { Hall facility, hostels, roads, } \\
& \text { water supply \& sewerage } \\
& \text { system changed } \\
\checkmark & \text { Faculty of Architecture was } \\
\text { dropped }\end{array}$ & $\begin{array}{ll}\checkmark & \text { Strategy revised. } \\
\checkmark & \text { Infrastructure changes } \\
& \text { introduced }\end{array}$ & \\
\hline $\begin{array}{l}\text { 6. Has there been any alteration } \\
\text { or distortion? What are some of } \\
\text { the internal and external factors } \\
\text { responsible for the alteration or } \\
\text { distortion? }\end{array}$ & $\begin{array}{ll}\checkmark & \text { Distortion \& alterations } \\
\text { occurred due to: } \\
\checkmark \text { University Council's \& } \\
\text { Building Committee's } \\
\text { flexibility to master plan } \\
\text { changes } \\
>\text { Effective management }\end{array}$ & $\begin{array}{l}\text { Distortions/alterations } \\
\text { were made in response to } \\
\text { changing needs \& } \\
\text { circumstances over time }\end{array}$ & $\begin{array}{l}\text { Master plan is } \\
\text { dynamic } \\
\text { reflecting } \\
\text { prevailing } \\
\text { operational } \\
\text { strategies and } \\
\text { influenced by }\end{array}$ \\
\hline
\end{tabular}




\begin{tabular}{|c|c|c|c|}
\hline & $\begin{array}{l}>\text { Multi-campus approach } \\
>\text { Fast growth in student } \\
\text { population } \\
>\text { Delay in construction } \\
>\text { Student \& community } \\
\\
\text { security risks }\end{array}$ & & $\begin{array}{l}\text { internal and } \\
\text { external factors }\end{array}$ \\
\hline $\begin{array}{l}\text { 7. What is your perception of } \\
\text { the level of effectiveness of the } \\
\text { internal organ or committee } \\
\text { responsible for the monitoring } \\
\text { and evaluation of the } \\
\text { implementation of the } \\
\text { infrastructure master plan? }\end{array}$ & $\begin{array}{l}\checkmark \\
\text { Internal organs very } \\
\text { effective through } \\
\text { collaborative M \& E } \\
\checkmark \text { Accommodative to required } \\
\text { changes } \\
\checkmark \text { State-of-the-art buildings } \\
\text { are being constructed and } \\
\text { renovated } \\
\checkmark \\
\text { The committee's role was } \\
\text { curtailed by funding which } \\
\text { rendered it ineffective }\end{array}$ & $\begin{array}{l}\checkmark \text { Organ is effective \& } \\
\text { responsive } \\
\checkmark \text { Organ's effectiveness } \\
\text { curtailed by funding }\end{array}$ & $\begin{array}{l}\text { Monitoring \& } \\
\text { Evaluation: } \\
\text { Require effective } \\
\text { internal } \\
\text { operational } \\
\text { structure }\end{array}$ \\
\hline $\begin{array}{l}\text { 8. Do you have any suggestions } \\
\text { that will guide the } \\
\text { operatives/staff/committee } \\
\text { responsible for the development } \\
\text { and monitoring of the } \\
\text { implementation of the } \\
\text { infrastructure master plan, which } \\
\text { will enable them to do their } \\
\text { work more effectively? }\end{array}$ & $\begin{array}{ll}\checkmark & \text { Take initiative \& be } \\
\text { innovative even under a } \\
\text { constraining environment } \\
\checkmark & \text { Consult widely before } \\
\text { making any changes to the } \\
\text { master plan } \\
\checkmark \text { The plan must be reviewed } \\
\text { regularly not as mandatory } \\
\text { process but to align } \\
\text { activities with reality } \\
\checkmark \text { Consolidate infrastructure } \\
\text { development on existing } \\
\text { campuses } \\
\checkmark \text { Government must improve } \\
\text { country's economic } \\
\text { performance \& support } \\
\text { infrastructure funding more }\end{array}$ & $\begin{array}{l}\checkmark \text { Master plan must be } \\
\text { reviewed regularly to } \\
\text { align with reality } \\
\checkmark \\
\text { Channel resources to } \\
\text { consolidate infrastructure } \\
\text { development on existing } \\
\text { campuses } \\
\checkmark \text { Be creative even under } \\
\text { constraining environment } \\
\text { to develop infrastructure }\end{array}$ & $\begin{array}{l}\checkmark \text { Periodic reviews } \\
\text { of master plan } \\
\text { should involve } \\
\text { wide consultation } \\
\text { and alignment to } \\
\text { strategies }\end{array}$ \\
\hline $\begin{array}{l}\text { 9. What strategies could be } \\
\text { employed to ensure the } \\
\text { infrastructure master plan is } \\
\text { effectively implemented? }\end{array}$ & $\begin{array}{l}\checkmark \begin{array}{l}\text { Involve \& consult all } \\
\text { relevant stakeholders on } \\
\text { changes }\end{array} \\
\checkmark \quad \text { Involve \& consult all } \\
\text { relevant stakeholders on } \\
\text { changes } \\
\checkmark \quad \text { Engage \& involve people } \\
\text { with the right skills and } \\
\text { expertise } \\
\checkmark \quad \text { Explore alternative means } \\
\text { of funding e.g., PPP, BOT, } \\
\text { etc. other than relying on } \\
\text { government only }\end{array}$ & $\begin{array}{ll} & \text { Pursue mixed space } \\
\text { procurement strategies }\end{array}$ & $\begin{array}{l}\text { Adopt innovative } \\
\text { infrastructure } \\
\text { development } \\
\text { strategies }\end{array}$ \\
\hline
\end{tabular}

The five suitable themes, developed in Table 4, are interrelated (as shown in Figure 2) and the institution's management did some balancing acts to marshal resources at its disposal including formulating enabling policies and strategies to realise the objectives of the SIDMP. 


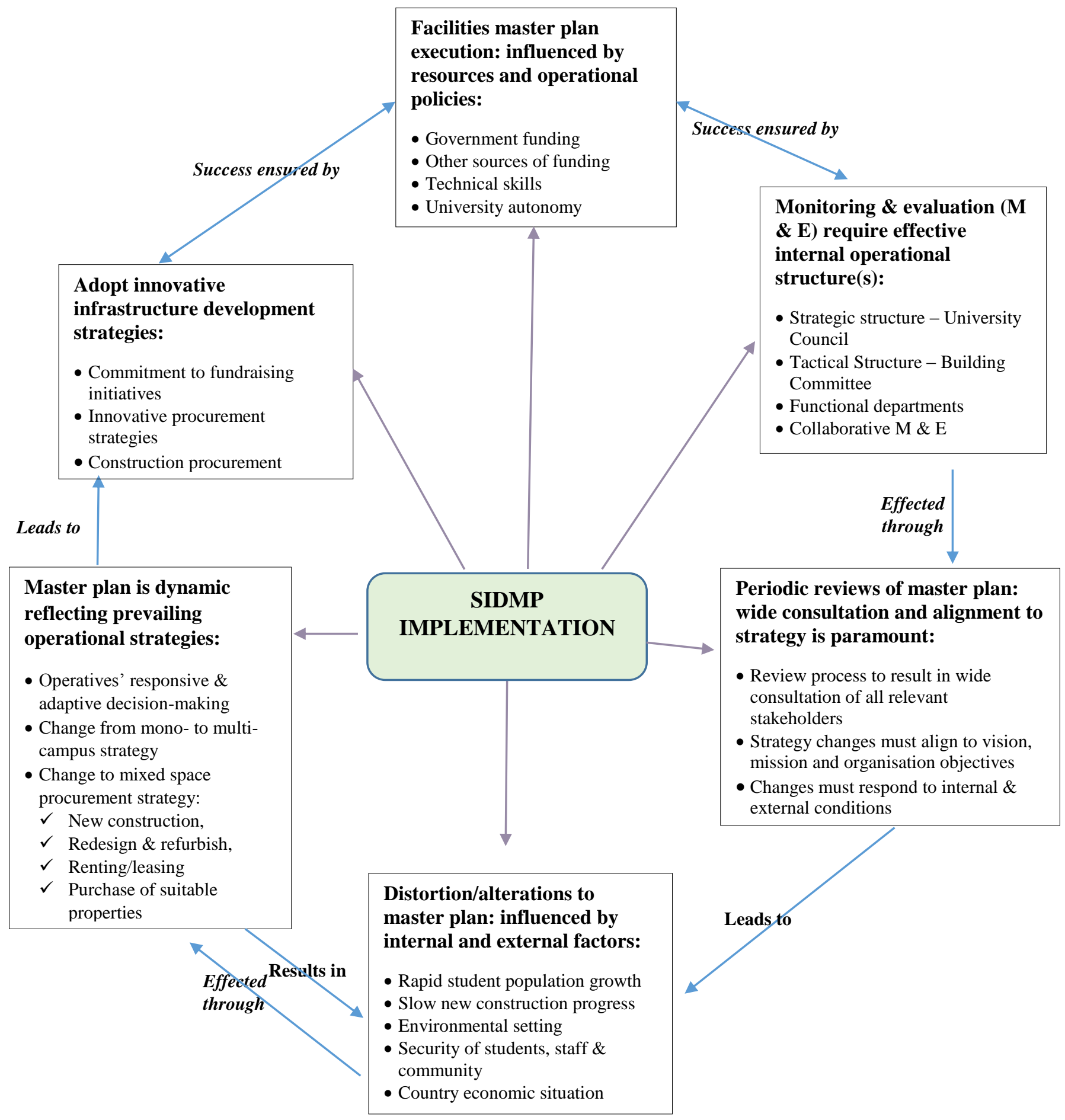

Fig. 2: Conceptual implementation model of the case study HE institution's SIDMP 


\subsection{Discussion of Research Findings}

The themes developed during the analysis of participants' responses are discussed sub-sections 4.3.1-4.3.5.

\subsubsection{SIDMP Implementation is Influenced by Resources and Operational Policies}

The effective implementation of the facilities master plan, by any organisation, including HE institutions, is influenced by the resources at the disposal of the organisation and the operational policies. Literature shows that infrastructure master plan development and implementation hinge on the availability of adequate resources [52]. Some of these critical resources include human capital, adequate finance, and required technology. These resources are central to the effective implementation of an infrastructure master plan [53] Therefore, resources such as competent professional in-house staff with adequate skill sets, funding and appropriate technology are important 'bundles of resources' that need to be exploited and combined for the successful implementation of infrastructure master plan [54]. It is one thing to have adequate personnel with the right skills in an organisation, however, the prevailing organisational structure, motivation, delegation of power and support from senior management facilitates, timely decision-making process for the effective implementation of the different phases and components of the master plan need to be in place to succeed [55], [56].

During the early stages of the implementation of the SIDMP, especially in the early part of Phase 1, the university enjoyed adequate funding support from the government, had competent human capacity at the strategic and operational levels, which facilitated the speedy execution of the facilities master plan. However, with the economic downturn, the low funding support from government coupled with the exodus of skilled personnel and the need to implement the new policies favouring a multicampus structure, compelled the institution to revise the original master plan, and develop suitable operational strategies.

\subsubsection{Master Plan is Dynamic, Reflecting Prevailing Operational Strategies and Influenced by Internal and External Factors}

Long-term infrastructure master plans for an $\mathrm{HE}$ institution are bound to change during the implementation phase. Changes are often driven by circumstances. Some of the factors that influence these changes include the dynamic change in academic programmes, variations in the level of funding, the increase or decrease in the student population, as well as other salient internal and external factors [46]. Implementing a strategic facilities master plan is a huge undertaking and it is inevitable that as the plan unfolds, changes sometimes substantial ones - must be made midproject to increase the chances of success [9]. The implementation of the institution's SIDMP was no exception, as changes to the original strategic plan occurred during the first review of the plan in 2005. The initial design of the SIDMP was for a large mono-campus. This was changed to four campuses in different locations in response to internal and external conditions. This strategic change affected the implementation of the facilities master plan significantly. Similarly, the sudden growth in student numbers compelled the university to re-arrange the execution of some parts of the planned projects. In this regard, the construction of the 'Great Hall' earlier than planned for during the third phase, (Table 2 ), was executed in the second phase, to provide space for examinations and graduation ceremonies.

The original campus is located on the periphery of a high-density residential suburb and most students resided within the community. Unfortunately, the community was affected each time there were student protests. This posed major safety and security challenges to the university and the proximate community. In a bid to reduce the high concentration of the student population in this growing sub-urban community, coupled with other intrinsic factors, the university dropped the strategy of having a monocampus in favour of a multi-campus system.

\subsubsection{Periodic Reviews of Master Plan Require wide Consultation and Alignment to Strategy}

In real life, infrastructure master plans are not cast in stone, but dynamic, responding to objective changes and strategic directions of the organization. Therefore, periodic reviews of the facilities master plan and its implementation are done to ensure that 
required adjustments or changes are made in response to the prevailing internal and external factors. The HE institution carried out two strategic plan reviews over the 15 -year plan horizon that resulted in changes in implementation strategies. The first strategic plan review saw the institution's strategy change from establishing a huge monocampus to multi-campuses located in other parts of Zimbabwe. The review also resulted in the alteration of its academic plan by dropping one faculty: the Faculty of Architecture, Art and Design. The response by the institution to the unfolding reality is consistent with the White Paper on Strategic Facility Planning [47, p. 18], that predicts that:

While implementation is in progress, flexibility to adapt to changed conditions may be required. ..., since any major change in market conditions, economic outlook or other forces could require varying degrees of change to the original document. ... The Strategic Facility Plan (SFP) is a major facility management tool used to support the organization alignment with the organizational vision, mission, goals, and objectives [and] is always critical for success of the SFP.

The exercise of changing an institution's policy framework or strategic plans to meet its objectives, requires continuous and broad-based consultations with all relevant stakeholders within and outside the organisation, to ensure the successful implementation of the strategy [13]. By adopting the principles of participatory governance $[48,49]$, the staff at the different levels of leadership in the HE institution's internal structure, responsible for the management, coordination and implementation of the facilities master plan were actively engaged in the review process. Sieving through suggestions, dynamic and objective debate of suitable options and consensus building, leading to strategic decisions on suitable amendments to be implemented [10].

The external stakeholders were equally engaged in the process that brought on board, the support of the private sector through public-private partnerships. The active involvement of all relevant stakeholders led to the wide acceptance of the changes in the implementation of the institution's SIDMP, resulting in its success. The HE institution was able to respond to the changing internal and external environment by aligning its learning and administrative spaces procurement strategies to meet its long-term academic and facility requirement objectives, through progressive consultations with stakeholders and the periodic monitoring and evaluation of processes, which facilitated the effective rollout of planned academic programmes.

\subsubsection{Monitoring and Evaluation Require Effective Internal Operational Structure}

According to Okumus [9], monitoring and evaluation, otherwise referred to as control and feedback, are essential organisational processes required for the effective execution of an infrastructure master plan. Control and feedback involve formal and informal mechanisms used to monitor and evaluate programme or project implementation against predetermined goals and objectives [9]. Furthermore, effective communication and operational plans are key to monitoring and evaluation, allowing senior management to receive timely feedback on implementation progress. In line with this framework, the HE institution's facilities plan was monitored at two levels: at the tactical level by the Building Committee and at strategic level by the University Council. The Building Committee provided oversight over the construction programme and was involved in the purchase or lease of properties from the market in response to changing demands for learning and administrative space. At strategic level, the University Council monitored the establishment of the academic programmes, in line with the availability of learning and administrative space, and timely approval of the proposals from the Building Committee. These internal operational structures used established control mechanisms to allocate resources, monitor and evaluate the performance of the delegated duties to ensure that the respective agencies of the institution are executing their functions and achieving the institution's strategic objectives [47]. The synergy between these two internal structures contributed significantly to the successes recorded in the implementation of the SIDMP of the institution, amid a challenging economic environment.

The Building Committee, charged with the responsibility of implementing the SIDMP, periodically assesses, monitors, coordinates, and tracks the progress of the SIDMP execution. The committee formally reports their results to the strategic leadership team and equally presents proposals for amendments, where necessary, for consideration and approval [9]. Conversely, the committee communicates with the Department of Works and Estates at the operational level. The 
Department of Works and Estates is the technical arm charged with the implementation of the facilities master plan. The department was responsible for all physical developments, contractors and project management, quality control and the compilation of progress reports. The effective coordination of the relationship between the strategic and operational levels of leadership by the Building Committee resulted in the adoption of innovative approaches during the implementation of the SIDMP.

\subsubsection{Adopt Innovative Infrastructure Development Strategies}

As the implementation of the HE institution's facilities master plan unfolded, the environment changed, and the University had to explore and adopt innovative development strategies. The implementation enabling factors on which the original strategic plan and facilities master plan were premised changed drastically, especially government funding support and prevailing economic conditions. According to Rowley [50], there are two things that are important to ensure the successful implementation of a campus strategic plan, namely, that strategic planners must know their options for implementing the plan and that the appropriate method of implementation should be selected. Among the several effective implementation methods, one of them is using the budget [50]. Under this circumstance, the university chose the method of strengthening their budget through innovative fundraising strategies, which include the pragmatic adoption of the principles of public-private partnership (PPP) agreements with financial institutions and other private organisations, to fund the construction of some of the facilities in the SIDMP.

Due to delays in the construction of new facilities because of lack of funding for capital projects, the university pursued a multi-pronged strategy of procuring space for learning and administrative purposes through rehabilitation, refurbishment, and adaptation of existing facilities, the leasing, or renting and purchasing of suitable existing facilities. The multi-pronged space procurement strategy was facilitated by operational strategies and the enabling policy of university autonomy that allowed the institution to create other sources of income rather than relying on traditional state funding only. As shown in Table 3, out of the 13 infrastructure projects executed within the planned period (IWPP); three of these projects were new constructions, three others were achieved through refurbishment, adaptation, or alterations, while seven of the projects were achieved through rental, lease, or purchase of suitable properties. This approach was adopted in the infrastructure projects executed earlier than the planned period (IEPP) as seen in Table 3. The pursuit of a multi-pronged space procurement strategy had an overarching influence on the achievement of the infrastructure strategic goals, of the university within the 15-year planned period. In this regard, the execution of the institution's SIDMP demonstrates that indeed the implementation of a strategy is dynamic, interactive and is a complex process that calls for management to set priorities, focus energy and resources, strengthen operations and coordinate everyone towards a common goal in response to the changing environment [49].

\section{Conclusion and Recommendations}

The development and implementation of an infrastructure master plan, which serves as the blueprint for realising the physical infrastructure needs of an HE institution, requires long-term operations and dogged commitments from all relevant stakeholders, especially key internal operatives. An infrastructure master plan is not cast in stone, but is subject to changes and objective modifications due to the dynamics within and outside the academic institution. Furthermore, modifications or outright changes can be influenced by internal and external factors, economic and political factors, as well as changes in the administrative leadership of the institution. It is imperative, therefore, to create a system that can guide successive administrations of the institution to consistently realign the execution of the infrastructure master plan towards achieving the strategic objectives of the institution. This is where the role of the internal operatives becomes critical.

The research revealed that the development and implementation of the SIDMP was achieved through the commitment and collaborative efforts of all the internal operatives involved. As is typical in any HE institution, the initial plan for a single large campus morphed into a multi-campus institution. However, the SIDMP was executed, despite harsh economic constraints; $19(82.6 \%)$ out of the 23 projects planned for the developmental period were successfully executed by adopting the multi-pronged approach of constructing new facilities, refurbishing, and 
rehabilitating existing facilities, renting, leasing, and purchasing suitable facilities. The internal operative and support structures that played the pivotal role at both the strategic and operational levels of leadership are the University Council, the Building Committee and Works and Estates Department. The synergy between these internal operatives facilitated effective control and feedback, which allowed continuous monitoring and evaluation of the different phases of the master plan implementation. The University Council provided the much-needed leadership, while the Building Committee provided the interface between the Council (strategic leadership) and the Department of Works and Estates (the operational leaders) saddled with the technical responsibilities of coordinating the implementation of the SIDMP. The synthesis of data collected from the respondents confirmed the invaluable role played by the internal operatives in navigating the daunting economic landscape, scarce financial resources, managing the modification of the master plan and many more, through the practice of participatory leadership and broad-based consultations.

In summary, "the focus of this paper is to explore the role played by specific internal organs of the institution in the implementation phase of the infrastructure master plan of the university". The research revealed that the University Council, the Building Committee and Works and Estates Department were the three key internal operating units that played significant roles in the successful implementation of the SIDMP of the HE institution, therefore, satisfying the research focus. Although this research was a single site case study of an HE institution, the role played by internal operatives has led to the successful implementation of the SIDMP. Based on this result, this research recommends that the principle can be adapted by other institutions or organisations involved in executing an infrastructure master plan. The strength of this concept lies in the 'collaborative relationship and participatory leadership'.

\section{Sources of Funding for Research Presented in a Scientific Article or Scientific Article Itself}

The publication of the article was financed in the framework of the contract no. DNK/SN/465770/2020 by the Ministry of Science and Higher Education within the "Excellent Science" programme.
References:

[1] Abiad, A., Almansour, A., Furceri, D., Granados, C. M., \& Topalova, P., World Economic Outlook: Is it time for an infrastructure push? The macroeconomic effects of public investment, IMF Research Department's Economic Modeling and Development Macroeconomics Divisions, 2014, available online at: http://www.eco.uc3m.es/temp/ppt_WEO_Ch3.p df Accessed 10 January 2021.

[2] Hameed, R., \& Nadeem, O., Challenges of Implementing Urban Master Plans: The Lahore Experience, International Journal of Humanities and Social Sciences, Educational, Economic, Business and Industrial Engineering, Vol. 2, No. 12, 2008, pp. 1297-1304.

[3] Pella, M. D. A., Sumarwan, U., \& Daryanto A., Factors Affecting Poor Strategy Implementation, Gadjah Mada International Journal of Business, Vol. 15, No. 2, 2013, pp. 183-204.

[4] Li, Y., Guohui, S., \& Eppler, M. J., Making strategy work: a literature review on the factors influencing strategy implementation. Institute of Corporate Communication, 2008, Available online at: https://www.researchgate.net/publication/49285 998 Accessed 12 April 2020.

[5] Kraaijenbrick, J., The Strategy Handbook: A practical and refreshing guide for making strategy work. Netherlands: Effectual Strategy Press, 2018.

[6] Hrebiniak, L.G., (2006). „Obstacles to Effective Strategy Implementation". Organisational Dynamics, 35, 12-31.

[7] Alharthy, A. H., Rashid, H., \& Khan, F., Identification of Strategy Implementation Influencing Factors and Their Effects on the Performance, International Journal of Business and Social Science, Vol. 8, 2017, pp. 34-44.

[8] Caruthers, J. K., \& Layzell, D. T., Campus Master Planning and Capital Budgeting, Roles and Responsibilities of the Chief Financial Officer: New Directions for Higher Education, No. 107, No. 99, 2003, p. 73.

[9] Okumus, F., A Framework to Implement Strategies in Organizations, Journal of Management Decision, Vol. 41, No. 9, 2003, pp. 871-882.

[10] Al-Kandi, I., Asutay, M., \& Dixon, R., Factors Influencing the Strategy Implementation Process 
and its Outcomes: Evidence from Saudi Arabian Banks, Journal of Global Strategic Management, Vol. 7, No. 2, 2013, pp. 5-15.

[11] Walleri, D. R., \& Becker, W. E., \& Linn, C., From Academic Vision to Physical Manifestation, 2002, available online at: https://eric.ed.gov/?id=ED467620 Accessed 12 April 2020.

[12]Lick, D. W., \& Kaufman, R., Change Creation: The Rest of the Planning Story, Journal of Planning for Higher Education, Vol. 29, No. 2, 2001, pp. 24-36.

[13] Rudden, M. S., Ten Reasons Why Colleges and Universities Undertake Campus Master Planning (and How to Align Your Campus Planning Effort to Best Address Them), Journal of Planning for Higher Education, Vol. 36, No. 4, 2008, pp. 33-41.

[14] University' Strategic $2001-2015$ (2001), $1^{\text {st }}$ Edition

[15] University' Strategic \& Business Plan 2001 2015 (2005), $2^{\text {nd }}$ Edition

[16] Zimbabwe Statistical Agency, (2013), Poverty and Poverty Datum Line Analysis in Zimbabwe 2011/12, available online at: http://www.zimstat.co.zw/wp-content/uploads/ publications /Income/ Finance/Poverty-Report2011.pdf. Accessed: 25 November 2020

[17] Reserve Bank of Zimbabwe (2009). Zimbabwe's Payment System under Multi Currency, https://www.sadcbankers.org/subcommittees/Pa ySystem/media/Documents/Newsletters/Vulindl ela_Dec2009/Zimbabwe_article.pdf, downloaded 25/01 18

[18] Federal Reserve Bank of Dallas, (2011). Hyperinflation in Zimbabwe, Globalization and Monetary Policy Institute 2011 Annual Report. https://www.dallasfed.org/assets/documents/insti tute/annual/2011/annual11b.pdf, Accessed 28 January 2018

[19] Guckert, D. J., \& King, J. R., The High Cost of Building a Better University, Journal of Planning for Higher Education, Vol. 32, No. 2, 2004, pp. 24-29.

[20] Colyer, A., \& Seeger, C., Crafting the Master Plan: A Collaborative Challenge for Community Colleges, Journal of Planning for Higher Education, Vol. 35, No. 3, 2007, pp. 63-69.

[21] Van der Merwe, M. M., \& Nienaber, H., Factors Hindering Strategy Implementation as Perceived by Top, Middle and Frontline Managers in a
South African Electronics Organization, Journal of Global Business and Technology, Vol. 11, No. 2. 2015 https://core.ac.uk/download/pdf/7917 0749.pdf Accessed 18 May 2020.

[22] Mohamed, H. A. B., Ab. Ghani, A. M., \& Basir, S. A., Factors Influencing the Implementation of Islamic QMS in a Malaysian Public Higher Education Institution, Total Quality Management and Business Excellence, Vol. 27, No. 9-10, 2016, pp. 1140-1157.

[23]Maria, T. D., \& Vasile, B., Modern Trends in Higher Education Funding, 5th World Conference on Educational Sciences, Procedia Social and Behavioral Sciences 116, 21 Feb. 2014, pp. 2226-2230, Elsevier, 2013.

[24] Hitt, M. A., Ireland, R. D., \& Hoskinson, R. E., Strategic Management: Competitiveness and Globalization. 10th Ed. USA, Mason: Cengage Learning, 2013.

[25] Bryson, J. M., \& Alston, F. K., Creating and Implementing Your Strategic Plan: A workbook for Public and Nonprofit Organizations (Vol. 1). USA: John Wiley \& Sons, 2010.

[26] Kotler, P., \& Murphy, P. E., Strategic Planning for Higher Education, The Journal of Higher Education, Vol. 52, No. 5, 1981, pp. 470-489.

[27] Jacobs, A., \& Walker, S., Introduction to Research in Education, 9th Ed, USA, Wadsworth: Cengage Learning, 2014.

[28] Horwitz, F. M., Heng, C. T., \& Quaz, H. A., Finders, Keepers? Attracting, Motivating and Retaining Knowledge Workers, Human Resource Management Journal, 2006, Online: https://doi.org/10.1111/j.1748-8583.2003.tb0010 3.x Accessed 19 December 2020.

[29] Omondi, M. P., Ombui, K., \& Mungatu, J., Factors Affecting Effective Strategy Implementation for Attainment of Millennium Development Goal 5 by International Reproductive Health Non-governmental Organizations in Kenya, The TQM Journal, Vol. 25, 2013, pp. 507-519.

[30] Zhang, Q., Ning, K., \& Barnes, R., A Systematic Literature Review of Funding for Higher Education Institutions in Developed Countries, Frontiers of Education in China, Vol. 11, No 4, 2016, pp. 519-542.

[31] Okebukola, P., ed., Towards Innovative Models for Funding Higher Education in Africa, Association of African Universities, 2015. 
Available online at: https://aau.org/webinars/resources/english-aaufunding-book.pdf Accessed 18 November 2020.

[32] Alexander L., \& Drumm, K., A Master Facilities Planning Process that Focuses on ROI, Planning for Higher Education Journal, Vol. 45, No.1, 2016, pp. 1-12. https://search.proquest.com/openview/55902b3b 7d84b8a542c752c3ddd585b3/1?pq-

origsite $=$ gscholar $\& \mathrm{cbl}=47536 \quad$ Accessed 18 December 2020.

[34] Mgaiwa, S. J., 2018, Paradox of Financing Public Higher Education in Tanzania and the Fate of Quality Education: The Experience of Selected DOI:10.1177/2158244018771729 Accessed online 27 January 2021.

[35] Geuna, A., \& Rossi, F., The University and the Economy: Pathways to Growth and Economic Development. UK: Edward Elgar Publishing Limited, 2015.

[36] Otieno, F. A. O., The Roles of Monitoring and Evaluation in Projects, Project Management Scientific Journal, Vol. 1, Issue 5, 2019, pp. 4144.

[37] Walter, J., Kellermanns, F. W., Floyd, S. W., Veiga, J. F., \& Matherne, C., Strategic Alignment: A Missing Link in the Relationship Between Strategic Consensus and Organizational Performance, Journal of Strategic Organization, Vol. 11, No. 3, 2013, pp. 304-328.

[38] Ivancic, V., Mence, I., Jelenc, L., \& Dulcic, Z., Strategy Implementation - External Environment Alignment, Journal of Contemporary Management Issues, Vol. 22, Special Issue, 2017, pp. 51-67.

[39] Venkatraman, N., \& Prescott, J. E., Environment-Strategy Co-alignment: An Empirical Test of its Performance Implications, Journal of Strategic Management, Vol. 11, 1990, p. 23.

[40] Zajac, E. J., Kraatz, M. S., \& Bresser, R. K. F., Modeling the Dynamics of Strategic Fit: A Normative Approach to Strategic Change, Strategic Management Journal, Vol. 21, No. 4, 2000, pp. 429-53.

[41] Mnjama, M. D., \& Koech, P., Factors Affecting Implementation of Strategic Plans at Wellcome Trust Research Programme, The Strategic
Journal of Business \& Change Management, Vol. 6, No. 2, 2019, pp. 892-913.

[42] Merriam, S. B., Qualitative Research: A Guide to Design \& Implementation, USA: John Wiley \& Sons Inc, 2009.

[43] Yin, R. K., Case Study Research: Design \& Methods, 4th Ed., USA, California: SAGE Publication, 2009.

[44 Robson, C., Real World Research: A Resources for Users of Social Research Methods in Applied Settings, 3rd Ed., USA, Winchester: Wiley, 2011.

[45] Aryl, D., Jacobs, L. C., Sorensen, C. K., \& Walker, D. A., Introduction to Research in Education, 9th Ed, USA, Wadsworth: Cengage Learning, 2014.

[46] Kriken, J. L., Principles of Campus Master Planning, Journal of Planning for Higher Education, Vol. 32, No. 4, 2004, pp. 31-46.

[47] International Facility Management Association, Strategic Facility Planning: A White Paper. IFMA, 2009, https://www.ifma.org Accessed 10 November 2020.

[48] Fung, A., \& Wright, E. O., Deepening Democracy: Institutional Innovations in Empowered Participatory Governance, USA, New York: Verso, 2003.

[49] Fischer, F., The Oxford Handbook of Governance: Participatory Governance - From Theory to Practice. Online Publication. DOI:10.1093/oxfordhb/9780199560530.013. 0032, 2012.

[50] Rowley, D. J., \& Sherman, H., Implementing the Strategic Plan, Journal of Planning for Higher Education, Vol. 30, No. 4, 2002, pp. 514.

[51] Drucker, P. F., The Practice of Management, USA: Harper Business, 2006.

[52] Aaltonen, B., \& Ikavalko, H. (2013). Implementing strategies successfully. Integrated Manufacturing Systems, 13(6), 415-418.

[53] Downie, R., \& Kennedy, B., Center for Strategic and International Studies Sudan: Assessing risks to stability. 2011. Online:

https://www.researchgate.net/publication/27343 9956_Accessed 19 December 2020.

[54] Wilcoxson, J. E., (2012). Strategic planning implementation: A case study of a California community college. Doctoral Thesis). California State University, Fresno, available online at: 
http://csufresno-

dspace.calstate.edu/bitstream/handle/10211.3/11 8776/JesseWILCOXSON. pdf? sequence $=1$. Accessed on December 2, 2020.

\section{[56]}

Brinkschröder,N., (2014). Strategy

Implementation: Key Factors, Challenges and

Solutions, 4th IBA Bachelor Thesis Conference, Enschede, The Netherlands.[55] Al-Kandi, I., Asutay, M., \& Dixon, R., Factors influencing the strategy implementation process and its outcomes: evidence from Saudi Arabian banks, Journal of Global Strategic Management, Vol. 7, No. 2, 2013, pp. 5-15.
Creative Commons Attribution License 4.0 (Attribution 4.0 International, CC BY 4.0)

This article is published under the terms of the Creative Commons Attribution License 4.0

https://creativecommons.org/licenses/by/4.0/deed.en $\underline{\mathrm{US}}$ 